\title{
Influence of Lime and Phosphorus on Growth Performance and Nutrient Uptake by Indian Spinach (Basella alba L.) Grown in Soil
}

\author{
Ashoka Sarker, Md. Abul Kashem*, Khan Towhid Osman \\ Department of Soil Science, University of Chittagong, Chittagong, Bangladesh \\ Email: ${ }^{*}$ kashem00@yahoo.com
}

Received 20 January 2014; revised 20 February 2014; accepted 27 February 2014

Copyright (C) 2014 by authors and Scientific Research Publishing Inc.

This work is licensed under the Creative Commons Attribution International License (CC BY).

http://creativecommons.org/licenses/by/4.0/

(c) (i) Open Access

\begin{abstract}
A pot experiment was carried out to determine the effect of lime and phosphorus on the growth and nutrient uptake by Indian spinach (Basella alba $\mathrm{L}$.) on an acidic soil. The experimental soil was amended with four levels of lime $\left(0,500,1000\right.$ and $\left.2000 \mathrm{~kg} \mathrm{CaCO}_{3} \mathrm{ha}^{-1}\right)$ and phosphorus (P) $\left(0,50,100\right.$, and $\left.150 \mathrm{~kg} \mathrm{P} \mathrm{ha}^{-1}\right)$ and their combinations. The results showed that lime and $P$ applied separately or in combination had significant $(P<0.001)$ effects on growth parameters (height and number of leaves), fresh and dry weight of shoot and root and $N, K$ and Ca uptake by Indian spinach. Combined application of lime and $P$ gave a better result than the separate application of lime and P. Application of $2000 \mathrm{~kg} \cdot \mathrm{ha}^{-1}$ lime plus $150 \mathrm{~kg} \mathrm{P} \mathrm{ha}^{-1}$ had higher uptake of $\mathrm{N}, \mathrm{K}$ and Ca and better morphological characters that eventually resulted in greater yield compared with other treatments. The results revealed that lime and phosphorus could be used in combination to improve growth performance and nutrient uptake when plants grown in an acidic soil.
\end{abstract}

\section{Keywords}

Acid Soil; Lime; Phosphorus; Basella alba; Growth; Nutrient Uptake

\section{Introduction}

In acid soils, availability of certain nutrients like aluminium, iron and manganese increases due to higher dissolution and at times becomes toxic. In strongly acidic conditions, phosphorus reacts with active iron and alumi-

${ }^{*}$ Corresponding author.

How to cite this paper: Sarker, A., Kashem, Md.A. and Osman, K.T. (2014) Influence of Lime and Phosphorus on Growth Performance and Nutrient Uptake by Indian Spinach (Basella alba L.) Grown in Soil. Open Journal of Soil Science, 4, 98-102. http://dx.doi.org/10.4236/ojss.2014.43013 
nium forming insoluble phosphates. Yuan et al. [1] and Mandal and Khan [2] observed that more than 80 per cent of applied phosphate was converted into unavailable forms in acid soils within very short periods. Under such conditions, calcium and magnesium supply is reduced and plant growth suffers. In addition to these, other beneficial nutrients such as nitrogen, phosphorus, and sulfur are also in deficient concentration [3].

To meet the calcium demands as well as to create favourable conditions for better uptake of other essential nutrients liming is an important management practice in acid soils. The overall effects of lime on soils include among others, increased soil $\mathrm{pH}, \mathrm{Ca}$ and $\mathrm{Mg}$ saturation, neutralization of toxic concentrations of aluminum, increase in $\mathrm{pH}$ dependent CEC resulting in absorption and hydrolysis of $\mathrm{Ca}^{2+}\left(\mathrm{Mg}^{2+}\right)$, increase in $\mathrm{P}$ availability and improved nutrient uptake by plants [4] [5]. Liming also improves microbiological activities of acid soils, which in turn can increase di-nitrogen fixation and liberate nitrogen $(\mathrm{N})$ from incorporated organic materials [6]. However, over liming may reduce crop yields due to lime induced $\mathrm{P}$ and micronutrient deficiencies [7]. Therefore, crop yield responses to lime and P are often interdependent [8]. Under these situations, an appropriate combination of lime and $\mathrm{P}$ is an important strategy for improving crops growth in highly weathered acid soil. In view of the above facts, the present investigation was undertaken to study the effect of lime and $\mathrm{P}$ and their combinations on the growth and nutrient uptake by Indian spinach.

\section{Materials and Methods}

\subsection{Plant Growth Experiment}

A pot experiment was carried out in the crop field of the University of Chittagong, Bangladesh, using a sandy loam surface soil $(0-15 \mathrm{~cm})$. Soil sample was air dried and passed through 4-mm sieve for using it in the pots. For laboratory analysis, a sub sample was air dried and passed through a 2-mm sieve and stored. Soil $\mathrm{pH}$ was of 5.07 (1:2.5 soil to water ratio), organic carbon [9] was of $0.98 \%$ and CEC (extraction with $1 \mathrm{~N} \mathrm{NH}_{4} \mathrm{OAc}$ ) [10] was of $4.18 \mathrm{cmol} \cdot \mathrm{kg}^{-1}$. The soil contained $69 \%$ sand, $16 \%$ silt and $16 \%$ clay measured by hydrometer method [11]. Exchangeable calcium was of $0.02 \%$ (extraction with $1 \mathrm{~N} \mathrm{NH}_{4} \mathrm{OAc}$ ) determined by atomic absorption spectrophotometry (AAS). The treatment consisted of four lime levels i.e., 0, 500, 1000 and $2000 \mathrm{~kg} \mathrm{CaCO}_{3}$ $\mathrm{ha}^{-1}$ and four phosphorus (P) levels, i.e., 0, 50, 100 and $150 \mathrm{~kg} \mathrm{P} \mathrm{ha}^{-1}$ of soil and lime and phosphorus combinations. Studies were conducted in earthen pots with $5 \mathrm{~kg}$ of soil in each pot. Five seeds of Indian spinach were sown to each pot and water was applied up to the field capacity. After emergence, 3 healthy seedlings were kept in each pot. A basal dose of 25:25 kg per ha of $\mathrm{N}$ and $\mathrm{K}$ was given to the crop. The growth parameters including height and number of leaves were recorded at 35 and 70 days of growth. The plants were harvested at 70 days of growth. After harvest, the plants were separated into shoots and roots and fresh weight was recorded. The shoots and roots were air dried for several days and oven dried at $65^{\circ} \mathrm{C}$ for 72 hours and dry weight was recorded. Total nitrogen $(\mathrm{N})$, potassium $(\mathrm{K})$ in the soil and in the plant tissues were determined by Kjeldahl and flame photometric methods, respectively and calcium (Ca) in the plant tissues by atomic absorption spectrophotometry after digestion with $\mathrm{H}_{2} \mathrm{O}_{2}-\mathrm{H}_{2} \mathrm{SO}_{4}$. Total $\mathrm{N}$ and $\mathrm{K}$ concentration in the experimental soil were $0.09 \%$ and $0.28 \%$ respectively.

\subsection{Statistical Analysis}

Microsoft Excel and MINITAB program [12] were used for analysis of variance and correlation. The nutrient uptake of the plants was calculated by multiplying the nutrient concentration in the tissue and the dry matter (DM) yield.

\section{Results and Discussion}

\subsection{Plant Height and Number of Leaves}

Variations in shoot height and number of leaves of Indian spinach observed due to application of lime in soil ( $P$ $<0.001$ ) at 35 and 70 days of growth (Table 1). Maximum height and number of leaves were obtained from $2000 \mathrm{~kg}$ lime except the height at 35 DAS. Significant variations in height and number of leaves at two stages of growth were also observed due to $\mathrm{P}$ fertilizer (Table 1). Application of $150 \mathrm{~kg} \mathrm{P}$ increased the growth parameters progressively giving maximum and the lowest values were obtained from $0 \mathrm{~kg} \mathrm{P}$ (Control). Among the combinations of lime and phosphorus level, the lime at $2000 \mathrm{~kg}$ and phosphorus at $150 \mathrm{~kg}$ recorded highest plant height at 70 DAS and maximum number of leaves at both stages of growth (Table 1). 
Table 1. Influence of lime and phosphorus on height $(\mathrm{cm})$ and number of leaves of Indian spinach at 35 and 70 days after sowing (DAS).

\begin{tabular}{|c|c|c|c|c|c|c|c|c|c|c|}
\hline \multirow{3}{*}{$\begin{array}{c}\text { Lime } \\
\text { levels } \\
\left(\mathrm{kg}^{\prime} \mathrm{ha}^{-1}\right)\end{array}$} & \multicolumn{10}{|c|}{ Phosphorus levels $\left(\mathrm{kg} \cdot \mathrm{ha}^{-1}\right)$} \\
\hline & 0 & 50 & 100 & 150 & Mean & 0 & 50 & 100 & 150 & Mean \\
\hline & \multicolumn{5}{|c|}{ Height at 35 DAS (cm) } & \multicolumn{5}{|c|}{ Height at 70 DAS (cm) } \\
\hline 0 & 5.63 & 10.72 & 15.57 & 17.70 & $12.41 b$ & 7.37 & 17.0 & 24.0 & 27.33 & $18.93 c$ \\
\hline 500 & 7.90 & 13.93 & 16.60 & 16.60 & $14.40 \mathrm{a}$ & 10.13 & 22.50 & 27.77 & 33.77 & $23.54 b$ \\
\hline 1000 & 6.73 & 8.70 & 16.47 & 16.47 & $12.39 b$ & 11.07 & 17.0 & 33.63 & 41.23 & $25.31 b$ \\
\hline 2000 & 8.70 & 10.50 & 15.23 & 15.23 & $13.69 b$ & 12.57 & 29.23 & 34.53 & 45.33 & $30.42 \mathrm{a}$ \\
\hline \multirow[t]{2}{*}{ Mean } & $7.24 \mathrm{~d}$ & $10.93 c$ & $15.97 b$ & $15.97 a$ & & $10.28 \mathrm{~d}$ & $21.01 \mathrm{c}$ & $29.98 b$ & $36.92 \mathrm{a}$ & \\
\hline & \multicolumn{5}{|c|}{ Number of leaves at 35 DAS } & \multicolumn{5}{|c|}{ Number of leaves at 70 DAS } \\
\hline 0 & 8 & 15 & 19 & 19 & $15 c$ & 11 & 20 & 23 & 30 & $21 c$ \\
\hline 500 & 13 & 20 & 24 & 28 & $21 b$ & 17 & 31 & 37 & 45 & $32 b$ \\
\hline 1000 & 10 & 19 & 26 & 31 & $21 b$ & 14 & 34 & 48 & 59 & $38 b$ \\
\hline 2000 & 17 & 25 & 27 & 34 & $26 a$ & 24 & 39 & 54 & 68 & $46 a$ \\
\hline Mean & $12 \mathrm{c}$ & $20 b$ & $24 a$ & $28 a$ & & $16 \mathrm{~d}$ & $31 c$ & $40 \mathrm{~b}$ & $50 a$ & \\
\hline
\end{tabular}

Means followed by the same letter(s) in column(s) or row(s) are not significantly different at $\mathrm{P}<0.05$.

\subsection{Fresh and Dry Weight of Shoot and Root}

Table 2 shows fresh and dry weight of shoot and root resulting from treatments. Both lime and P applied alone or in combination had significant effects $(P<0.001)$ on these yield parameters. The trend of treatments effect was similar on both fresh and dry weight. Maximum dry weight of shoot (17.12 g·pot ${ }^{-1}$ ) was obtained from 2000 $\mathrm{kg}$ lime followed by $1000 \mathrm{~kg}$ lime. Untreated control plants (without lime) gave the lowest value $\left(5.29 \mathrm{~g} \cdot \mathrm{pot}^{-1}\right.$ ) and it was statistically identical with $500 \mathrm{~kg}$ lime (Table 2). Application of $1000 \mathrm{~kg}$ lime increased dry weight of root progressively giving maximum (3.27 g·pot ${ }^{-1}$ ) followed by $2000 \mathrm{~kg}$ lime. Plants grown without lime gave the lowest root weight $\left(1.35 \mathrm{~g} \cdot\right.$ pot $\left.^{-1}\right)$. Both the shoot and root dry weights were higher in pots treated with 150 kg P. However, difference in shoot and root dry weight due to 100 and $150 \mathrm{~kg}$ P was not statistically significant. Although lime and P increased shoot and root yield, this effect was boosted by combining lime with P applied. Application of $2000 \mathrm{~kg}$ lime with $150 \mathrm{~kg}$ P increased shoot yields by 52-fold and root yields by 28-fold over control (Table 2). Increased dry matter yield of Indian spinach due to liming is attributed to the beneficial effect of ameliorating the soil, which increased the Ca-saturation and availability of major nutrients, especially nitrogen. Higher vegetative growth in Indian spinach must have caused efficient extraction of nutrients resulting in higher dry matter production [3]. A maximum yield in the study was obtained at the application of $2000 \mathrm{~kg}$ lime with $150 \mathrm{~kg}$ P indicating that the soil was effectively neutralized and calcium ions retained on exchange complex. Adsorption of a basic cation like $\mathrm{Ca}^{2+}$ on the exchange complex will increase the availability of nutrients due to cation exchange [13].

\subsection{Nutrient Uptake}

The total nitrogen uptake significantly $(P<0.001)$ differed in relation to different levels of lime and $\mathrm{P}$ applied singly or in combination (Table 3). Application of $2000 \mathrm{~kg} \cdot \mathrm{ha}^{-1}$ lime recorded higher total nitrogen uptake (457 $\mathrm{mg} \cdot$ pot $^{-1}$ ) than other levels of lime. Addition of $\mathrm{CaCO}_{3}$ increased soil $\mathrm{pH}$ and might have accelerated the process of mineralization of nitrogen which in turn promoted the uptake of nitrogen [3]. Similar results were also reported by Doddamani [14] and Patil and Ananthanaryana [15] when acid soils were limed. Among the different levels of phosphorus the crop receiving $150 \mathrm{~kg} \mathrm{P} \mathrm{ha}^{-1}$ recorded higher nitrogen uptake (486 mg·pot ${ }^{-1}$ ) than other levels (Table 3). Higher level of P application might have synergistic effect on $\mathrm{N}$ uptake by Indian spinach [3]. Application of $2000 \mathrm{~kg} \cdot \mathrm{ha}^{-1}$ lime plus $150 \mathrm{~kg} \mathrm{P} \mathrm{ha}{ }^{-1}$ showed maximum nitrogen uptake $\left(790 \mathrm{mg}^{-p^{-1}}\right.$ ) than other combinations. Uptake of $\mathrm{N}$ obtained by combining $1000 \mathrm{~kg}$ lime with $50 \mathrm{~kg} \mathrm{P}$ about five times the plant $\mathrm{N}$ uptake obtained from $50 \mathrm{~kg} \mathrm{P}$ applied alone (Table 3).

The total potassium uptake by Indian spinach was significantly $(P<0.001)$ influenced by separate or combined application of different levels of lime and P (Table 3). Increasing rates of lime up to $1000 \mathrm{~kg}$ enhanced $\mathrm{K}$ uptake by plant and further addition of lime above $1000 \mathrm{~kg} \cdot \mathrm{ha}^{-1}$ decreased the uptake. The decrease in $\mathrm{K}$ uptake 
Table 2. Influence of lime and phosphorus on fresh and dry weight of shoot and root (g·pot ${ }^{-1}$ ) of Indian spinach after harvest.

\begin{tabular}{|c|c|c|c|c|c|c|c|c|c|c|}
\hline \multirow{3}{*}{$\begin{array}{c}\text { Lime levels } \\
\left(\mathrm{kg}^{\prime} \mathrm{ha}^{-1}\right)\end{array}$} & \multicolumn{10}{|c|}{ Phosphorus levels $\left(\mathrm{kg} \cdot \mathrm{ha}^{-1}\right)$} \\
\hline & 0 & 50 & 100 & 150 & Mean & 0 & 50 & 100 & 150 & Mean \\
\hline & \multicolumn{5}{|c|}{ Fresh weight of shoot $\left(\mathrm{g} \cdot \mathrm{pot}^{-1}\right)$} & \multicolumn{5}{|c|}{ Dry weight of shoot $\left(g \cdot p^{-1}\right)$} \\
\hline 0 & 4.40 & 32.81 & 77.53 & 98.91 & $53.40 \mathrm{c}$ & 0.51 & 6.32 & 9.65 & 13.67 & $7.78 \mathrm{~d}$ \\
\hline 500 & 7.40 & 66.14 & 103.25 & 110.24 & $70.30 c$ & 0.95 & 12.97 & 17.84 & 19.75 & $13.07 d$ \\
\hline 1000 & 41.22 & 112.01 & 189.17 & 203.45 & $136.50 \mathrm{~b}$ & 3.81 & 21.37 & 23.44 & 24.04 & $18.67 \mathrm{a}$ \\
\hline 2000 & 69.75 & 155.31 & 207.78 & 218.50 & $163.40 \mathrm{a}$ & 5.09 & 12.29 & 21.81 & 24.99 & $15.87 b$ \\
\hline \multirow[t]{2}{*}{ Mean } & $30.6 c$ & $92.20 \mathrm{~b}$ & $144.40 \mathrm{a}$ & $157.80 a$ & & $2.59 c$ & 13.33b & 18.19a & $20.61 a$ & \\
\hline & \multicolumn{5}{|c|}{ Fresh weight of root $\left(\mathrm{g} \cdot \operatorname{pot}^{-1}\right)$} & \multicolumn{5}{|c|}{ Dry weight of root $\left(g \cdot \operatorname{pot}^{-1}\right)$} \\
\hline 0 & 1.49 & 6.32 & 9.65 & 13.67 & 7.78d & 0.16 & 0.92 & 1.84 & 2.48 & $1.35 d$ \\
\hline 500 & 1.69 & 12.97 & 17.84 & 19.75 & 13.07d & 0.23 & 4.13 & 2.62 & 2.98 & $1.83 \mathrm{c}$ \\
\hline 1000 & 5.81 & 21.37 & 23.44 & 24.04 & $18.67 \mathrm{a}$ & 1.10 & 3.67 & 4.13 & 4.17 & $3.27 \mathrm{a}$ \\
\hline 2000 & 4.06 & 12.29 & 21.81 & 24.99 & $15.87 b$ & 0.52 & 2.43 & 3.96 & 4.40 & $2.83 \mathrm{~b}$ \\
\hline Mean & $3.26 \mathrm{c}$ & $13.33 b$ & 18.19a & 20.61a & & $0.50 \mathrm{c}$ & $2.13 \mathrm{~b}$ & $3.14 \mathrm{a}$ & 3.51a & \\
\hline
\end{tabular}

Means followed by the same letter(s) in column(s) or row(s) are not significantly different at $P<0.05$.

Table 3. Influence of lime and phosphorus on nutrient uptake $\left(\mathrm{mg}^{\mathrm{p}} \operatorname{pot}^{-1}\right)$ by Indian spinach.

\begin{tabular}{|c|c|c|c|c|c|}
\hline \multirow{2}{*}{$\begin{array}{l}\text { Lime levels } \\
\left(\mathrm{kg}^{-h^{-1}}\right)^{-}\end{array}$} & \multicolumn{5}{|c|}{ Phosphorus levels $\left(\mathrm{kg} \cdot \mathrm{ha}^{-1}\right.$ ) } \\
\hline & 0 & 50 & 100 & 150 & Mean \\
\hline \multicolumn{6}{|c|}{ Nitrogen Uptake $\left(\mathrm{mg} \cdot\right.$ pot $\left.^{-1}\right)$} \\
\hline 0 & 3.41 & 50.45 & 151.8 & 225.4 & $107.8 \mathrm{c}$ \\
\hline 500 & 10.01 & 107.7 & 263.9 & 375.2 & $175.7 \mathrm{c}$ \\
\hline 1000 & 35.60 & 280.8 & 458.2 & 606.9 & $345.3 b$ \\
\hline 2000 & 57.68 & 361.8 & 618.9 & 789.6 & $457.2 \mathrm{a}$ \\
\hline Mean & $26.68 \mathrm{~d}$ & $200.4 c$ & $372.5 b$ & $486.4 \mathrm{a}$ & \\
\hline \multicolumn{6}{|c|}{ Potassium Uptake $\left(\mathrm{mg} \cdot \operatorname{pot}^{-1}\right)$} \\
\hline 0 & 6.14 & 45.79 & 139.6 & 255.1 & $111.7 \mathrm{~b}$ \\
\hline 500 & 12.76 & 91.93 & 253.1 & 306.5 & $166.2 \mathrm{~b}$ \\
\hline 1000 & 56.61 & 284.4 & 614.2 & 893.6 & $464.1 \mathrm{a}$ \\
\hline 2000 & 68.11 & 267.4 & 557.0 & 901.4 & 415.5 \\
\hline Mean & $35.90 \mathrm{~d}$ & $172.6 \mathrm{c}$ & $391.0 \mathrm{~b}$ & $558.0 \mathrm{a}$ & \\
\hline \multicolumn{6}{|c|}{ Calcium Uptake (mg·pot ${ }^{-1}$ ) } \\
\hline 0 & 1.89 & 17.0 & 46.7 & 67.7 & 33.3d \\
\hline 500 & 11.52 & 62.8 & 134.8 & 144.7 & $88.4 \mathrm{c}$ \\
\hline 1000 & 54.57 & 178.1 & 288.7 & 326.1 & $211.9 b$ \\
\hline 2000 & 85.14 & 249.6 & 387.0 & 461.0 & $295.7 \mathrm{a}$ \\
\hline Mean & $38.30 \mathrm{c}$ & $126.9 \mathrm{~b}$ & 214.3a & 249.9a & \\
\hline
\end{tabular}

Means followed by the same letter(s) in column(s) or row(s) are not significantly different at $P<0.05$.

with lime addition may be related to antagonistic effect of $\mathrm{Ca}$ and $\mathrm{Mg}$ on uptake of $\mathrm{K}$ [16]. These results are in accordance with those of Ananthanarayana and Perur [17], Sudhir [18] and Patil [19]. Application of phosphorus at the rate of $150 \mathrm{~kg} \mathrm{P} \mathrm{ha}{ }^{-1}$ recorded maximum potassium uptake (558 mg.pot ${ }^{-1}$ ) than other levels of phosphorus. Among the combinations, $\mathrm{K}$ uptake by plant followed a pattern similar to that obtained for $\mathrm{N}$ uptake (Table 3).

The total calcium uptake differed significantly $(P<0.001)$ with respect to application of different levels of lime and $\mathrm{P}$ applied alone or in combination (Table 3). Application of lime at $2000 \mathrm{~kg} \cdot \mathrm{ha}^{-1}$ recorded highest total calcium uptake (296 mg.pot ${ }^{-1}$ ) compared to other lime levels. Application of $150 \mathrm{~kg} \mathrm{P} \mathrm{ha}^{-1}$ recorded higher total calcium uptake (250 mg.pot $\left.{ }^{-1}\right)$ and it was statistically identical with $150 \mathrm{~kg} \mathrm{P} \mathrm{ha}^{-1}$. The pattern of Ca uptake by plant treated with various combinations of lime $\mathrm{P}$ levels was similar to that obtained for $\mathrm{N}$ and $\mathrm{K}$ uptake (Table 3). 


\section{Conclusion}

The results conclude that application of lime and phosphorus offers a large scope for better performance of Indian spinach. Application of lime along with phosphatic fertilizer at $2000 \mathrm{~kg} \cdot \mathrm{ha}^{-1}$ and $150 \mathrm{~kg} \cdot \mathrm{ha}^{-1}$ favoured the uptake of $\mathrm{N}, \mathrm{K}$ and $\mathrm{Ca}$ under acidic soil condition and this should be taken into consideration for cultivating plants in acidic soil condition. All the plant benefits were observed at the highest level of lime and P tested. If higher levels of lime and $\mathrm{P}$ were taken, the results of variation could be different and it would have been convenient to estimate the optimum requirement of lime and P. Further works in this regard are needed.

\section{References}

[1] Yuan, T.L., Robertson, W.K. and Neller, J.R. (1960) Form of Newly Fixed Phosphorus in 3 Acid Soils. Soil Science Society of America Proceedings, 24, 447-450. http://dx.doi.org/10.2136/sssaj1960.03615995002400060010x

[2] Mandal, L.N. and Khan, S.K. (1972) Release of Phosphorus from Insoluble Phosphatic Materials in Acidic Low Land Rice Soils. Journal of the Indian Society of Soil Science, 20, 19-25.

[3] Ranjit, R., Dasog, G.S. and Patil, P.L. (200) Effect of Lime and Phosphorus Levels on Nutrient Uptake by Groundnut Genotypes in Acid Soils of Coastal Agro Eco System of Karnataka. Karnataka Journal of Agricultural Sciences, 20, 631-633.

[4] Nicholaides, J.J., Sanchez, P.A. and Buol, S.W. (1983) Proposal for the Oxisol-Ultisol. Network of IBSRAM, North Carolina State University, Raleigh, 16.

[5] Oguntoyinbo, F.I., Aduayi, E.A. and Sobulo, R.A. (1996) Effectiveness of Some Local Liming Materials in Nigeria as Ameliorant of Soil Acidity. Journal of Plant Nutrition, 19, 999-1016. http://dx.doi.org/10.1080/01904169609365176

[6] Fageria, N.K., Zimmermann, F.J.P. and Baligar, V.C. (2010) Lime and Phosphorus Interactions on Growth and Nutrient Uptake by Upland Rice, Wheat, Common bean and corn in an Oxisol. Journal of Plant Nutrition, 18, 2519-2532. http://dx.doi.org/10.1080/01904169609365176

[7] Fageria, N.K. (1984) Response of Rice Cultivars to Liming in Certado Soil. Pesquisa Agropecuária Brasileira, Brasilia, 19, 883-889.

[8] Friesen, D.K., Juo, A.S.R. and Miller, M.H. (1980) Liming and Lime-Phosphorus-Zinc Interactions in Two Nigerian Ultisols. I. Interactions in the Soil. Soil Science Society of America Journal, 44, 1221-1226. http://dx.doi.org/10.2136/sssaj1980.03615995004400060018x

[9] Walkley, A. and Black, I.A. (1934) An Examination of Degtjareff Method for Determining Soil Organic Matter and a Proposed Modification of the Chromic Acid Titration Method. Soil Science, 37, 29-33. http://dx.doi.org/10.1097/00010694-193401000-00003

[10] Soil Survey Laboratory Staff (1992) Soil Survey Laboratory Methods Manual. Soil Survey Laboratory Investigations Report No. 42, USDA-SCS, Washington DC.

[11] Bouyoucos, G.J. (1962) Hydrometer Method Improved for Making Particle Size Analysis of Soils. Agronomy Journal, 54, 464-465. http://dx.doi.org/10.2134/agronj1962.00021962005400050028x

[12] Minitab. Inc. (1996) Minitab User Guide Release 11. Minitab, State College.

[13] Megdoff, F.R. and Bartlett, R.J. (1980) Effect of Liming Acid Soils on Potassium Availability. Soil Science, 129, 1214. http://dx.doi.org/10.1097/00010694-198001000-00003

[14] Doddamani, V.S. (1975) Effect of Liming Materials on the Yield and Uptake of Added Calcium by Groundnut in Two Acid Soils of Karnatka. M.Sc. Thesis, University of Agricultural Sciences, Bangalore.

[15] Patil, P.L. and Ananthanarayana, R. (1989) Effect of Lime Level as Indicated by Different Methods on Soil Properties. Karnataka Journal of Agricultural Sciences, 2, 273-380.

[16] Fageria, N.K. (1983) Ionic Interactions in Rice Plants from Dilute Solutions. Plant Soil, 70, 309-316. http://dx.doi.org/10.1007/BF02374887

[17] Ananthanarayana, R. and Perur, N.G. (1972) Effect of Liming on Nutrient Uptake in Ragi and Nutrient Status of Soil. Current Research, 11, 97-98.

[18] Sudhir, K. (1983) Ca-Mg-K Interrelationship in Soils and Crop. M.Sc. Thesis, University of Agricultural Sciences, Bangalore.

[19] Patil, P.L. (1986) Studies on Lime Requirement of AcidS of Uttara Kannada District, Karnataka State. M.Sc. Thesis, University of Agricultural Sciences, Dharwad. 